\title{
INTEGRATION OF SUPPLY CHAIN PERFORMANCE WITH CUSTOMER VALUES THROUGH COMBINING ANALYTICAL NETWORK PROCESS AND BAYESIAN NETWORK
}

\author{
MALEKI, M[eysam]; BASHKITE, V[iktoria] \& MACHADO, V[irgilio] C[ruz]
}

\begin{abstract}
Development of integration model for supply chain has been the concern of many scholars in the new century. Although a comprehensive integration model is not yet developed. However, different research works has shed light on different aspects of it .This research propose combination of analytical network process and Bayesian network to generate a novel supply chain integration model. Analytical network process is used in the enterprise side of the model where experts study applicable practices while Bayesian network is employed on the downstream end where end customer is receiving outputs (product / services). Combining these two methods enables supply chains to prioritize practices based on end customer preferences resulting in higher customer perceived values. In addition, the marginal benefit is reduction of over production as the most harmful waste.

Keywords: supply chain integration, customer value, analytical network process, Bayesian network
\end{abstract}

\section{INTRODUCTION}

The proposed model employs analytical network process (ANP) and Bayesian network (BN) in order to develop an integration model which is capable of handling technical, organizational, market, and strategic decision making procedure. ANP will be used to evaluate alternatives considering measures while $\mathrm{BN}$ will be employed on the other end to assess measures from end customer perspectives. This model aims to take advantage of tacit and explicit knowledge of experts as well as embracing market uncertainties.

Supply chain management (SCM) strives to put together different enterprises, firms, and companies which are involved in development of products and services. In order to achieve this aim it is required to quantitatively and qualitatively align internal practices with expectations of the end customer [1]. The proposed model takes benefits from ANP and BN to reach this alignment.

It should be noted that there are some limitations to this work. Firstly, the proposed model is not customized for any specific settings so when it comes to implementation phase, practitioners should apply specific characteristics of their enterprise to the model. Secondly, interpretation of customer values differs from case to case, so some of them may not be applicable to every enterprise.

The paper is organized as follows: Sections two to five provide required theoretical foundations in supply chain integration, customer value, ANP, and BN. Thereafter, the fifth section in dedicated to model presentation.

\section{SUPPLY CHAIN INTEGRATION}

The Council of Supply Chain Management Professionals (CSCMP) Defines Supply Chain Management as "Supply chain management encompasses the planning and management of all activities involved in sourcing and procurement, conversion, and all logistics management activities. Importantly, it also includes coordination and collaboration with channel partners, which can be suppliers, intermediaries, third party service providers, and customers. In essence, supply chain management integrates supply and demand management within and across companies" [1]. Supply chain integration may also be defined as a process of interaction and collaboration in which companies in a supply chain work together in a cooperative manner to arrive at mutually acceptable outcomes [2]. Importance of SCM was stressed on early 80's by [3] and in the same decade integration was pointed out as a strategic winning factor by [4]. SC's are generally complex and are characterized by numerous activities spread over multiple functions and organizations, which pose challenges to reach effective SC integration [5]. SCM is an interdisciplinary topic that addresses diverse fields: materials management, quality, industrial markets, purchasing, logistics, inventory, procurement, production planning, intra- and inter-organizational relationships, policy making, etc. Collaboration between buyer and supplier or building of a relationship lies at the core of SC [6-8].

The general idea is that integrative practices and a high level of integration have a positive impact on corporate and supply chain performance. Uncertainty seems to be one of the most important aspects of SCM and a number of studies pay attention to it [9].

Many companies have been concerned with development of SC measures through which they can measure and eventfully increase the profitability of participants of their supply chain. A key issue in SCM is to develop a measurement system to enable coordination mechanism for joint decision making [10] that can align objectives of independent members and coordinate their activities so as to optimize performance of the whole chain [11]. In addition, a smooth and well controlled material flow lies at the heart of best supply chain design and practice [12].

\section{CUSTOMER VALUES}

It has become relatively common knowledge that marketing managers must understand what their 
customers' value in order to survive and grow in competitive markets [13]. The objective of most analyses of supply chain management is to satisfy the end customer. Without value, there is little likelihood of any sustainable market oriented development, yet research into consumer value is still underdeveloped [14]. Research by [15] and [16] trace the concept of value in the literature and provide a wide range of definitions and opinions about this ambiguous concept. Truly understanding customer value is fundamental to marketing and customer behavior theory. Approaches and paradigms in industrial engineering claim to provide value for the end customer [17]. Marketing scholars also emphasize the need for a better understanding of customer values as a key point to be successful in the market [13].

Since perceived value influences customer satisfaction and, ultimately, customer retention and retail loyalty it is of high strategic importance to most enterprises [18-20]. Perceived customer value represents the customer's appraisal of the benefits received in an exchange tempered by the costs associated with obtaining those benefits, including qualitative and quantitative, and subjective and objective attributes [21].

Customer value represents the trade-off between benefits and sacrifices that stem from a provider's product and relationship resources which customers believe are facilitating their goals [22]. From enterprise perspective also purchasing managers in the twenty-first century play a more strategic role in their organizations than they did in the middle of the twentieth century and as such, the more strategically they look at suppliers and SC's [13].

The current research categorizes customer value into six elements taken from the literature, namely Time [23], [24], Quality[16], [25], Cost [24], Customization [26], Know-how [27], and Respect for the environment [28].

\section{ANALYTICAL NETWORK PROCESS}

The ANP is a generalization of the Analytic Hierarchy Process (AHP). The AHP is a theory of relative measurement with absolute scales of both tangible and intangible criteria based on the judgment of knowledgeable and expert people. How to measure intangibles is the main concern of the mathematics of the AHP. The AHP breaks down a problem into a hierarchy in which each decision element is considered to be independent; thus, it cannot accommodate interrelationships among elements [29-32]. The ANP extends the AHP to problems with dependence and feedback. Contrary to AHP, ANP provides a more generalized model in decision-making without making assumptions about the independency of the higher-level elements from lower-level elements and also of the elements within a level [33]. To [32] ANP is a comprehensive decision-making technique that has the capability to include all the relevant criteria, which have some bearing, in arriving at a decision. ANP allows for more complex interrelationships among decision elements by replacing the hierarchy in the AHP with a network [34]. This method portrays a real world representation of the problem under consideration by prioritizing not only just the elements but also groups or clusters of elements as is often necessary. ANP has nonlinear structure and allows interdependencies, therefore it goes beyond AHP [35],[36].

\section{BAYESIAN NETWORK}

BN also known as belief networks or Bayes nets in short form, belong to the family of probabilistic graphical models which are employed to represent knowledge about uncertain domain. BN combine principles from graph theory, probability theory, computer science, and statistics [37]. BN can reflect dependency relationship between variables under uncertain condition and can unify expert's prior experience, $\mathrm{BN}$ have sound probabilistic semantics, explicit encoding of relevance relationships which led $\mathrm{BNs}$ to be one of the best methods for dealing with uncertainty in the AI domain [38].

It has been appeared as a powerful practical tool to represent knowledge. A BN is a graphical model that encodes probabilistic relationships among variables of interest. BN model has below advantages in data analysis [39]:

- Because the model encodes dependencies among all variables; it readily handles situations where some data entries are missing.

- It can be used to learn causal relationships, and hence can be used to gain understanding about a problem domain and to predict the consequences of intervention.

- Since the model has both a causal and probabilistic semantics; it is an ideal representation for combining prior knowledge (which often comes in causal form) and data.

$\mathrm{BN}$ is a statistical model which is capable of computing the posterior probability distribution of any unobserved stochastic variables, given the observation of complementary subset variables [40]. Several authors [41-44] have recommended this approach as a comprehensive method to derive relationships and influences among variables. This approach has also been successfully used in a variety of topics related to supply chain.

\section{PROPOSED MODEL}

The proposed framework puts its foundation on six values. On one end these values are evaluated and prioritized according to end customer preferences. On the other end, SC experts employ specific practices to achieve those values.

From the industry side, three actors are defined as management, marketing, and technical. Initially the actor will pick the preferred category among strategic, technical, organizational, and market. Selection of corresponding SC practice takes place in each category. In addition, categories as classified are separated from actors to enable them getting involved in different matters. Six measures are identified for the system as quality, time, cost, customization, know-how, and respect for environment. These six measures will be used in the BN model to evaluate market demands as well. Thereafter, based on selected category, alternatives will 


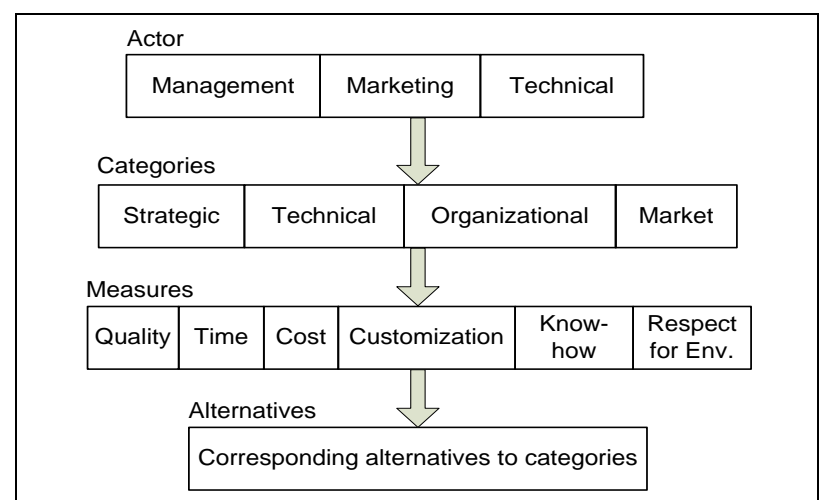

Fig. 1. ANP framework of the proposed model

be prioritized by the actor (Fig. 1). The ANP model is constructed by and for enterprise experts. Application of ANP in supply chain related topics has been mostly concentrated on development of decision support systems. For instance, [45] developed an ANP-based framework for modeling metrics of supply chain performance or [46] developed a decision support system to select suppliers for Indian textile industry by using ANP based on Fuzzy simulation.

Due the high level of uncertainty and interdependencies among variable, $\mathrm{BN}$ is used in the very end where the product is handed over the customer. Initially the target market sector is selected. Statistical formula (i.e. Cocharan) is used to find related sample size so that statistical methods will be applied to the data sample. The same measures which were used in the ANP model are used in this section as well to collect data on customers' preferences. Application of common measures both in manufacturing and customer sides facilitate practical understanding of marketing experts about manufacturing phase and vice versa. Thereafter, depending to standard variance of data sample, two or more states will be defined for measures (Fig. 2).

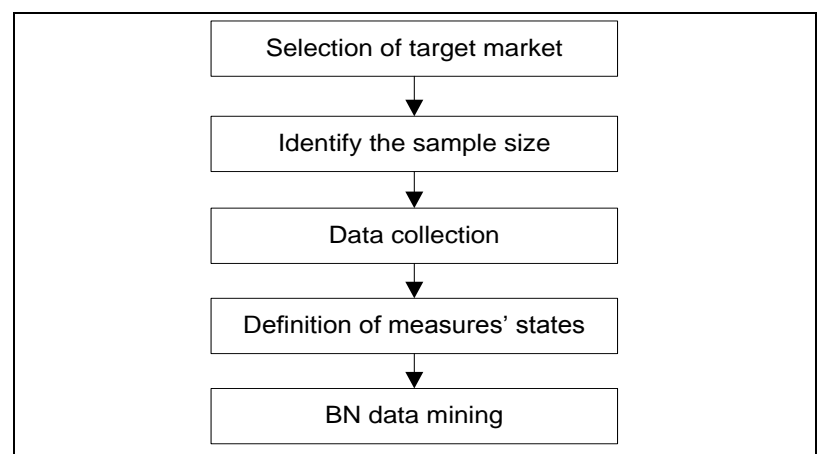

Fig. 2. BN framework of the proposed model

The proposed model is a combination of ANP and BN approach. As it is illustrated in Fig. 3 the two approached as being followed in enterprise and market side and they share the same criteria.

Internal experts employ specific strategic, technical, organizational, and market performances which are leading to improvements in customer perceived values. As it is discussed by [47] the literature agrees that comprehensive SC integration is not feasible at the moment. However, the current research put forward a framework which can facilitate this procedure by establishing common metrics and incorporating customer considerations into SC performances.

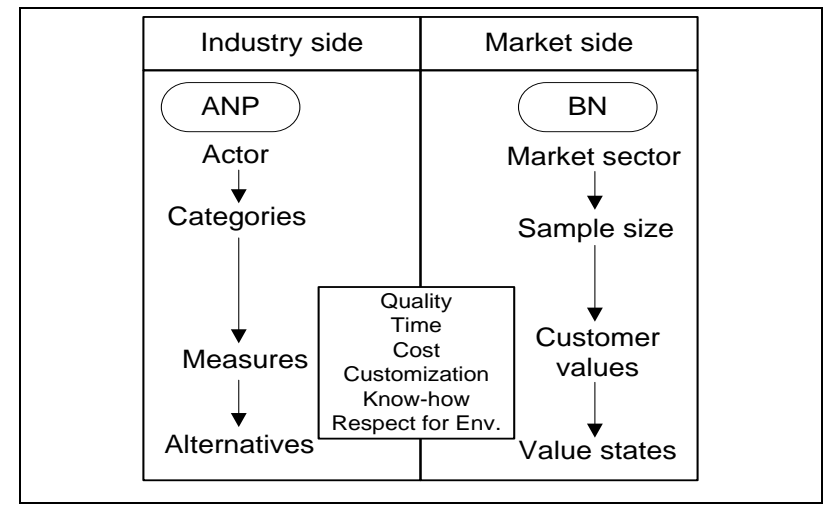

Fig. 3. Framework of the proposed model

Future research is required to address other aspects of SC integration such as financial integration of SC members, equitable share of risk and awards, trust building, and effective local and global positioning of SC.

\section{CONCLUSION}

The current research puts forward a model to integrate SC practices with customer values. The presented model incorporates ANP to find appropriate priority of SC practices according to six identified measures. In parallel, BN is employed in the market side to measure customer preferences and identify dependencies among those values.

The proposed model can be used in different SC's to facilitate decision making procedure as well as aligning internal activities with customer expectation. Due to the fact that the output of SC will be in line with demands, therefore a marginal benefit of the proposed model is reduction of over production that is considered as the most harmful waste.

Since a general perspective is taken in the development of the model, it requires proper customization in the implementation phase.

\section{ACKNOWLEDGEMENTS}

Authors thank the Fundação para a Ciência e Tecnologia da Faculdade de Ciências e Tecnologia, MIT Project MITPt/EDAM-IASC/0022/2008 for funding this research work.

\section{REFERENCES}

[1] http://cscmp.org/aboutcscmp/definitions.asp, Council of Supply Chain Management Professionals (CSCMP), Supply Chain Management Definitions. Accessed on: 2012-08-20

[2] Pagell, M. (2004). Understanding the factors that enable and inhibit the integration of operations, purchasing and logistics. Journal of Operations Management, Vol. 22, No. 5, pp. 459-487

[3] Oliver, R. K., \& Webber, M. D. (1982). Supply-chain management: logistics catches up with strategy. Outlook, Booz, Allen and Hamilton Inc

[4] Stevens, G. C. (1989). Integrating the supply chain. International Journal of Physical Distribution and Material Management, Vol. 19, No. 8, pp. 3-8

[5] Kanda, A., \& Deshmukh, S. G. (2008). Supply chain coordination: Perspectives, empirical studies and research directions. International Journal of Production Economics, Vol. 115, No. 2, pp. 316-335 
[6] Khalfan, M. (2012). Supply chain integration through innovative procurement. Malaysian construction research journal, Vol. 8, No. 1, pp. 52-70

[7] Lyu, J., Ding, J.-H., \& Chen, P.-S. (2010). Coordinating replenishment mechanisms in supply chain: From the collaborative supplier and store-level retailer perspective. International Journal of Production Economics, Vol. 123, No. 1, pp. 221-234

[8] Cheng, J. C. P., Law, K. H., Bjornsson, H., Jones, A., \& Sriram, R. (2010). A service oriented framework for construction supply chain integration. Automation in Construction, Vol. 19, No. 2, pp. 245-260

[9] Van Donk, D. P., \& Van Der Vaart, T. (2005). A Critical Discussion on the Theoretical and Methodological Advancements in Supply Chain Integration Research. Research Methodologies in Supply Chain Management (pp. 32-46). Physica - Verlag Heidelberg

[10] Kim, B., \& Oh, H. (2005). The impact of decision-making sharing between supplier and manufacturer on their collaboration performance. Supply Chain Management: An International Journal, Vol. 10, No. 3, pp. 223-236

[11] Wang, Y. (2010). Imprecise probabilities based on generalized intervals for system reliability assessment. International Journal of Reliability \& Safety, Vol. 4, No. 4, pp. 319-342

[12] Towill, D. R., Childerhouse, P., \& Disney, S. M. (2002). Integrating the automotive supply chain: where are we now? International Journal of Physical Distribution \& Logistics Management, Vol. 32, No. 2, pp. 79-95

[13] Flint, D. J., Blocker, C. P., \& Boutin Jr., P. J. (2011). Customer value anticipation, customer satisfaction and loyalty: An empirical examination. Industrial Marketing Management, Vol. 40, No. 2, pp. 219-230

[14] Sparks, B., Butcher, K., \& Bradley, G. (2008). Dimensions and correlates of consumer value: An application to the timeshare industry. International Journal of Hospitality Management, Vol. 27, No. 1, pp. $98-108$

[15] Graf, A., \& Maas, P. (2008). Customer value from a customer perspective: a comprehensive review. Journal für Betriebswirtschaft, Vol. 58, No. 1, pp. 1-20

[16] Gallarza, M. G., Gil-Saura, I., \& Holbrook, M. B. (2011). The value of value: Further excursions on the meaning and role of customer value. Journal of Consumer Behaviour, Vol. 10, No. 4, pp. 179-191

[17] Bei, L.-T., \& Shang, C.-F. (2006). Building marketing strategies for state-owned enterprises against private ones based on the perspectives of customer satisfaction and service quality. Journal of Retailing and Consumer Services, Vol. 13, No. 1, pp. 1-13

[18] Tu, Q., Vonderembse, M. A., \& Ragu-Nathan, T. . (2001). The impact of time-based manufacturing practices on mass customization and value to customer. Journal of Operations Management, Vol. 19, No. 2, pp. 201-217

[19] Cheung, M. F. Y., \& To, W. M. (2010). Customer involvement and perceptions: The moderating role of customer co-production. Journal of Retailing and Consumer Services

[20] Kim, Y. K., \& Smith, A. K. (2007). Providing a critical service today for tomorrow's consumers: A relational model of customer evaluations and responses in the child care industry. Journal of Retailing and Consumer Services, Vol. 14, No. 3, pp. 232-245

[21] Levenburg, N. M. (2005). Delivering customer value online: an analysis of practices, applications, and performance. Journal of Retailing and Consumer Services, Vol. 12, No. 5, pp. 319-331

[22] Blocker, C. P., Flint, D. J., Myers, M. B., \& Slater, S. F. (2010). Proactive customer orientation and its role for creating customer value in global markets. Journal of the Academy of Marketing Science, Vol. 39, No. 2, pp. 216-233

[23] Droge, C., Jayaram, J., \& Vickery, S. K. (2004). The effects of internal versus external integration practices on time-based performance and overall firm performance. Journal of Operations Management, Vol. 22, No. 6, pp. 557-573

[24] Whicker, L., Bernon, M., Templar, S., \& Mena, C. (2009). Understanding the relationships between time and cost to improve supply chain performance. International Journal of Production Economics, Vol. 121, No. 2, pp. 641-650

[25] Lee, W.-I., Chang, C.-Y., \& Liu, Y.-L. (2010). Exploring customers' store loyalty using the means-end chain approach. Journal of Retailing and Consumer Services, Vol. 17, No. 5, pp. 395-405

[26] Tseng, S.-M. (2012). Correlations between external knowledge and the knowledge chain as impacting service quality. Journal of Retailing and Consumer Services, Vol. 19, No. 4, pp. 429-437
[27] Gruen, T., Osmonbekov, T., \& Czaplewski, a. (2006). eWOM: The impact of customer-to-customer online know-how exchange on customer value and loyalty. Journal of Business Research, Vol. 59, No. 4, pp. 449-456

[28] Dibrell, C., Craig, J. B., \& Hansen, E. N. (2011). How managerial attitudes toward the natural environment affect market orientation and innovation. Journal of Business Research, Vol. 64, No. 4, pp. 401-407

[29] Tseng, M.-L., Chiang, J. H., \& Lan, L. W. (2009). Selection of optimal supplier in supply chain management strategy with analytic network process and choquet integral. Computers \& Industrial Engineering, Vol. 57, No. 1, pp. 330-340

[30] e Ambroggi, M., \& Trucco, P. (2011). Modelling and assessment of dependent performance shaping factors through Analytic Network Process. Reliability Engineering \& System Safety, Vol. 96, No. 7, pp. 849-860

[31] Wu, W.-W., \& Lee, Y.-T. (2007). Selecting knowledge management strategies by using the analytic network process. Expert Systems with Applications, Vol. 32, No. 3, pp. 841-847

[32] Chung, S.-H., Lee, A. H. I., \& Pearn, W. L. (2005). Analytic network process (ANP) approach for product mix planning in semiconductor fabricator. International Journal of Production Economics, Vol. 96, No. 1, pp. 15-36

[33] Jharkharia, S., \& Shankar, R. (2007). Selection of logistics service provider: An analytic network process (ANP) approach. Omega, Vol. 35, No. 3, pp. 274-289

[34] Kim, C., Lee, H., Seol, H., \& Lee, C. (2011). Identifying core technologies based on technological cross-impacts: An association rule mining (ARM) and analytic network process (ANP) approach. Expert Systems with Applications, Vol. 38, No. 10, pp. 12559-12564

[35] Ravi, V., Shankar, R., \& Tiwari, M. (2005). Analyzing alternatives in reverse logistics for end-of-life computers: ANP and balanced scorecard approach. Computers \& Industrial Engineering, Vol. 48, No. 2, pp. 327-356

[36] Agarwal, A., \& Shankar, R. (2002). Analyzing alternatives for improvement in supply chain performance. Work Study, 51(1), 32-37

[37] Gopnik, A., \& Tenenbaum, J. B. (2007). Bayesian networks, Bayesian learning and cognitive development. Developmental science, Vol. 10, No. 3, pp. 281-7

[38] Li, J., \& Gao, Y. (2010). Base on Bayesian Network of supply chain enterprises collaborative sensitivity analysis. 2010 International Conference on Logistics Systems and Intelligent Management (ICLSIM) Vol. 1, pp. 160-163

[39] Neapolitan, R. E. (2003). Learning Bayesian Networks. Prentice Hall, ISBN 0130125342

[40] Gambelli, D., \& Bruschi, V. (2010). A Bayesian network to predict the probability of organic farms' exit from the sector: A case study from Marche, Italy. Computers and Electronics in Agriculture, Vol. 71, No. 1, pp. 22-31

[41] Boudali, H., \& Dugan, J. (2005). A discrete-time Bayesian network reliability modeling and analysis framework. Reliability Engineering \& System Safety, Vol. 87, No. 3, pp. 337-349

[42] Langseth, H., \& Portinale, L. (2007). Bayesian networks in reliability. Conference on Mathematical Models in Reliability, Vol. 92, pp. 92-108

[43] Mahadevan, S., Zhang, R., \& Smith, N. (2001). Bayesian networks for system reliability reassessment. Structural Safety, Vol. 23, No. 3, pp. 231-251

[44] Muller, A., Suhner, M., \& Iung, B. (2008). Formalisation of a new prognosis model for supporting proactive maintenance implementation on industrial system. Reliability Engineering \& System Safety, Vol. 93, No. 2, pp. 234-253

[45] Agarwal, A., Shankar, R., \& Tiwari, M. K. (2006). Modeling the metrics of lean, agile and leagile supply chain: An ANP-based approach. European Journal of Operational Research, Vol. 173, No. 1, pp. 211-225

[46] Kumar, D., Singh, J., \& Singh, O. P. (2011). A decision support system for supplier selection for Indian textile industry using analytic hierarchy process based on fuzzy simulation. International Journal of Business Performance and Supply Chain Modelling, Vol. 3, No. 4, pp. 364-382

[47] Carter, P. L., Monczka, R. M., Ragatz, G. L., \& Jennings, P. L. (2009). Supply Chain Integration: Challenges and Good Practices. Institute for Supply Management and W. P. Carey School of Business at Arizona State University, ISBN 0945968752 